\title{
Terror Management Theory: Missiological Applications in Times of Crisis
}

David R. Dunaetz

Azusa Pacific University

\begin{abstract}
Terror Management Theory seeks to explain the human motivation to find meaning in life. The theory proposes that humans experience anxiety, even terror, when faced with the reality of their own mortality. To manage this anxiety, humans are motivated to adopt worldviews that indicate that they are significant (in contrast to meaningless) and that they will endure beyond death, either figuratively or literally. Global crises, such as natural disasters, terrorism, or war, make human mortality salient on a large scale. In such situations, humans are more than ever motivated to seek an afterlife, to act in a way to be remembered favorably after death, and to identify with communities that will transcend the duration of their own life. These conditions make some individuals especially open to the gospel which explains how humans can experience eternal life, how they can live righteous lives full of love, and how they can fit into both the Christian community and the Missio Dei. Missionaries should use this openness to the gospel in sensitive and loving ways to help victims of global crises discover a solution to the existential terror that they experience when facing their own mortality. The loving response of missionaries is to proclaim the Christian worldview so that people can make sense out of the crisis and respond positively to the gospel.
\end{abstract}




\section{Terror Management Theory: Missiological Applications in Times of Crisis}

The Old Testament begins with the creation of the world, the creation of humans, their moral failure leading to their death, and their attempts to justify what they had done (Gen. 1-3). The Epic of Gilgamesh (George 1999), from the third millennium before Christ, tells of a hero's attempt to gain eternal life. Thucydides, in the fifth century before Christ, speaks of the immortality that comes through righteous acts that are remembered by future generations of within one's community (II.43). The New Testament speaks often of eternal life, justification, and the triumph of Christ over death (e.g., John 3, Rom. 1-5, I Cor. 15). Concerns about death, meaning, and personal value have always concerned humanity. People's quest for value has long been recognized as a central issue in the scientific study of psychology (e.g., Adler 1927; Allport 1937; Horney 1937). As Ernest Becker wrote in The Denial of Death, "Of all things that move man, one of the principal ones is his terror of death" (1973, p. 11).

For over thirty years, this terror of death has been studied empirically and has led to terror management theory (Greenberg, Pyszczynski, and Solomon 1986; Solomon, Greenberg, and Pyszczynski 1991; Juhl and Routledge 2016) which describes the relationship between thoughts about death and the anxiety, and even terror, that it provokes. Such dread can be buffered and reduced by belief in literal or figurative immortality. When no such buffers exist, people seek sources of protection to reduce the anxiety they experience. Such behavior especially occurs when death is salient, even after the proximal cause of this salience (e.g., an act of terror or a writing prompt about one's own death) is no longer the direct focus of one's thoughts (Greenberg and Arndt 2011; Pyszczynski, Solomon, and Greenberg 2015).

When missionaries serve in contexts where death is widespread, such as when natural disasters and terrorism occur, they can expect to see the phenomena associated with terror management theory play out. The purpose of this study is to present some of the key findings from terror management research so that missionaries may know how to best respond when death and disaster strike. Such conditions make some individuals especially open to the gospel because of the existential terror that they experience when the certainty of their own death is made salient. How can missionaries, evangelists, and pastors communicate the gospel most effectively when death is salient? 


\section{Elements of Terror Management Theory}

Terror management theory addresses the causes and effects of the discomfort, anxiety, and dread that one experiences when death is prominent. The fear of meaninglessness, hopelessness, and lostness create a discomfort that motivates many behaviors in day-to-day life. The main elements of terror management theory are illustrated in Figure 1.

\section{Figure I}

Principal Elements of Terror Management Theory

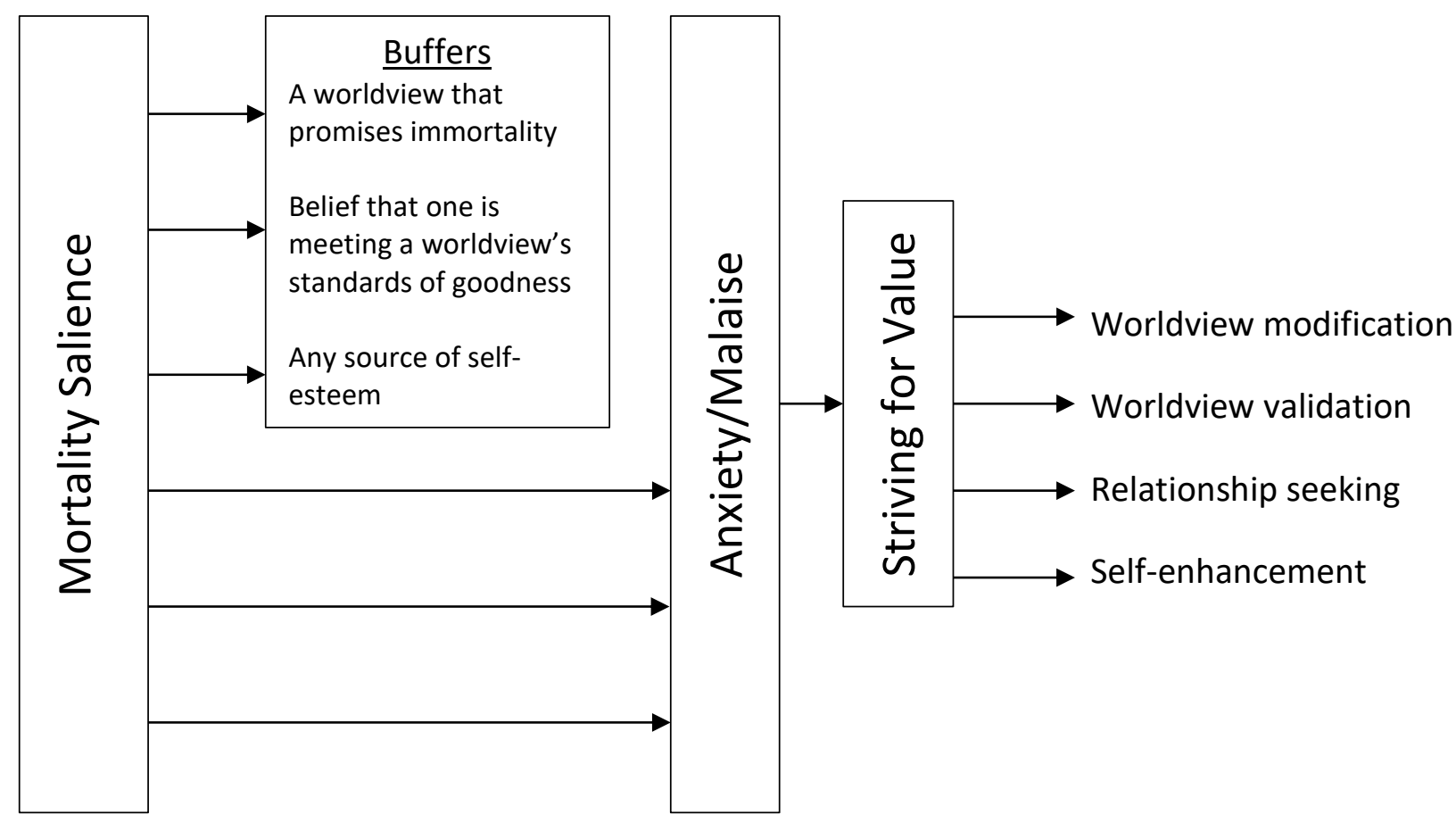

\section{Mortality Salience and Buffers}

When one's mortality is salient, such as when one reflects on their own certain death or the recent death of another person, it tends to produce anxiety or malaise, that is, a sense of terror, a fear, that affects everything we do unless it is somehow buffered (Greenberg and Arndt 2011). Unlike animals, only humans can think of their impending death and the accompanying possibility of annihilation, oblivion, or judgment. This results in terror unless they can buffer this fear through hope that 
their life will have some type of meaning or value, present or future, temporal or eternal. This hope depends on their worldview, which is highly influenced by religion or culture (Solomon, Greenberg, and Pyszczynski 1991; Juhl and Routledge 2016).

From a Christian perspective, this terror is similar to the "restlessness" that Augustine described as the state of man without God, "You have made us for yourself, O Lord, and our heart is restless until it rests in you" (Confessions Bk I. Par. 1). Similarly, Pascal described an emptiness in humans that can only be filled by God, "This infinite abyss can be filled only with an infinite and immutable object, in other words, by God himself" (Pensées, VII.425). The Bible itself clearly speaks of the certainty of future judgment (Heb. 9:27) and of the human need of justification to escape it (Rom. 1-5).

However, terror management theory is not just concerned with buffering from a Christian perspective. It has led to the discovery of other means that people use to buffer themselves psychologically from the effects of thinking about death. One of the principle buffers that people use is their cultural worldview, a set of beliefs that gives life purpose and meaning. These worldviews may be religious or secular. The essential elements of a worldview which are needed to provide a buffer include a definition of what is important and standards of behavior which provide a hope of literal or symbolic immortality if the individual lives up to these standards (Greenberg, Pyszczynski, and Solomon 1986; Pyszczynski, Solomon, and Greenberg 2015; Solomon, Greenberg, and Pyszczynski 1991). Literal immortality is promised by religious worldviews associated with Christianity and Islam. Symbolic immortality is associated with more secular cultural worldviews; one becomes immortal by being part of something greater than oneself that continues after one's death. These sources of symbolic immortality include being part of a great nation, making technological, literary, or artistic contributions to society, amassing wealth that is passed on to future generations, having a positive impact and being favorably remembered by those with whom one is close, or even supporting a famous sports team or closely identifying with a valued brand of electronic products (Arndt et al. 2004).

When death is salient, humans seek some form of immortality that serves as evidence of their goodness, value, and morality, and as justification for one's behavior and life (Greenberg, Pyszczynski, and Solomon 1986; Burke, Martens, and Faucher 2010). Thus, during times of crisis and natural disasters, people especially cling to their worldview if it offers such hope. For Christians, who seek justification through Christ's work rather than their own actions, this can result in a stronger faith and a greater assurance of the goodness of God's will. A recent study (Vail and Soenke 2018) compared the impact of mortality salience on meaning in life among Christians and atheists. When death was not salient, both Christians and non- 
Christians indicated that they experienced about equal meaning in life. However, after being made to reflect about their own death, the Christians' meaning in life rose significantly and the atheists' meaning in life decreased significantly. Not only does this provide evidence that the Christian worldview is a better buffer against the terror associated with death than secular worldviews, but it also indicates that nonChristians, especially those with materialistic worldviews, may be more open to finding meaning in life during times of disaster or other times when death is salient.

Evangelistic activities (e.g., special church services, meetings, or other activities where non-Christians can be presented the gospel; Dunaetz 2019) are especially important to organize soon after disasters or at other times when death is salient since non-Christians may be more open to the gospel and Christians tend to be more aware of their purpose in life. Meaning and purpose of life are especially relevant topics to address in such contexts. The creation narrative (Gen 1-3), Joseph's experience in Egypt (Gen 37-47), Job's trials (Job 1-2, 38-42), Esther's story, and Jeremiah's Lamentations are all excellent texts illustrating God's purposes in even the darkest times. Such stories can be linked to Christ's death and resurrection to give a clear presentation of God's offer of salvation to those who put their faith in him.

For a worldview to be an effective buffer against the terror of death, the individual must have the assurance that they are living in accordance with the standards set by the worldview so as to ensure immortality (Greenberg 2005; Pyszczynski, Solomon, and Greenberg 2015). A key aspect of the gospel is that one's sin prevents him or her from achieving literal immortality (Rom. 3:23). However, Christ's death on the cross enables those who put their faith in him to be justified and receive this immortality as an unmerited gift (Rom. 6:23). This divine offer of justification should be emphasized during times of disaster and death because it offers a much more accessible hope than the hope which comes from human efforts.

A second buffer against the anxiety caused by thoughts of death consists of one's close relationships (Figure 1; Jonas et al. 2002; Zaleskiewicz, Gasiorowska, and Kesebir 2015; Juhl and Routledge 2016; Plusnin, Pepping, and Kashima 2018). There are several reasons that close relationships act as a buffer. On a physical level, close relationships make survival in dangerous situations more likely; close others provide physical security, shared resources, and shared responsibility for protecting and nurturing children and others who are the most vulnerable. Most people, especially those with a secure attachment style (Griffin and Bartholomew 1994), are naturally comforted by others when confronted with the death of someone they know. Close others also provide a sort of symbolic immortality, expanding the boundaries of the self to include the community which will continue once the individual dies, as well as ensuring that memories of oneself will be transmitted to future generations. Furthermore, people seek validation of their cultural worldview 
through others' affirmation of the worldview, a process that most easily occurs within close relations.

Close relationships also act as a buffer against death anxiety because they increase a person's self-esteem and sense of justification; one of the main functions of self-esteem is to act as a measure of the quality of one's relationships, being high when relationships are healthy and low when they are not (Leary et al. 1995). Moreover, it appears that any source of self-esteem acts as a buffer when one' mortality is salient (Greenberg, Pyszczynski, and Solomon 1986). Meeting the moral standards defined by one's worldview and close relations bolsters one's self-esteem and provides a buffer against death-inspired anxiety, but so does self-enhancement, "the tendency to maintain unrealistically positive self-views" (Dufner et al. 2019; Krueger 1998). Self-enhancement occurs in a wide range of situations and is associated with a wide range of psychological phenomena including overconfidence (Moore and Healy 2008), self-serving biases (Miller and Ross 1975), the better-thanaverage effect (Alicke et al. 1995), unrealistic optimism (Weinstein and Klein 1996), self-love (Campbell, Rudich, and Sedikides 2002), and narcissism (Grijalva and Harms 2014). This implies that people who are characterized by these traits or frequently experience these phenomena, as well as those buffered by a strong worldview or many close relationships, will be the least open to the gospel during crises. Conversely, those without these buffers will likely be more open to the gospel due to the anxiety that they feel when forced to reflect on their own mortality.

\section{Mortality Salience and Anxiety}

The second major phenomena in terror management is the existential terror or anxiety that is produced by unbuffered mortality salience (Figure 1.). Many of the hundreds of experimental studies conducted to confirm and refine terror management theory have confirmed that anxiety, as well as fear, is indeed experienced by those who are faced with their own mortality (Greenberg and Arndt 2011; Juhl and Routledge 2016; Kastenbaum and Heflick 2010). Terror management is often studied from a "theologically neutral" point of view (McNamara, Sosis, and Wildman 2011) or from a purely materialistic point of view (Greenberg and Arndt 2011; Solomon, Greenberg, and Pyszczynski 1991) which assumes that religion is a human-created response to the certainty of one's death. However, from a Christian point of view, God has "put eternity in their heart" (Ecc. 3:11) and this ability to reflect upon our final destiny is a consequence of being made in the image of God (Gen. 1:27). The anxiety that we feel comes from our damaged relationship with God (Gen. 3:8-10) and the likelihood of judgment due to our inability to keep "the requirements of the law written on [our] hearts" (Rom. 2:15). 
One of the more surprising discoveries of terror management theory is that anxiety reactions increase as a function of time after an event that makes a person think of his or her own death. The proximal reaction, which occurs immediately after a person is primed to think about death (such as being asked to write about what one thinks will happen after death), tends to be only weakly associated with anxiety. In general, people can write about what they think they will experience in a rational way, without much anxiety. However, if the mortality salience intervention (e.g., the writing prompt) is followed by a distractor task (such as taking a personality test or solving a puzzle), the distal reaction is much stronger and the provoked anxiety is much stronger, presumably as a result of one's mortality being processed subconsciously (Burke, Martens, and Faucher 2010; Juhl and Routledge 2016; Greenberg and Arndt 2011).

This difference between proximal and distal reactions to mortality salience is also seen in real-life disasters. When a disaster occurs, such as an earthquake, hurricane, or act of terrorism, people tend to be quite rational and pro-social as soon as they become aware of the situation (Gantt and Gantt 2012). They tend to evaluate the situation quickly, including risk identification and risk assessment, to develop an action plan to save themselves and others in the most effective way possible. Once they have insured their own mobility, they tend to be very concerned with others and are ready to make sacrifices to save others from death and suffering. During the disaster and during the rescue period, they tend to experience a psychological numbness which permits them to act rationally to address the immediate needs (Lebedun and Wilson 1989). Only afterwards, once the immediate danger is over, do they respond emotionally, often being overwhelmed by the suffering and damage caused by the disaster.

From a missiological perspective, our response as Christians should be to join immediately to help those in danger, focusing, like the good Samaritan, on responding to whatever immediate physical need we can (Luke 10:25-37). However, once the immediate danger is over, it is appropriate to respond to people's spiritual needs by responding to issues that people deal with when thinking about their own death: anxiety, sadness, dread, judgment (by God and by other humans), fulfilment, life goals, the afterlife, and the response of loved ones (Kastenbaum and Heflick 2010). These issues can be addressed in private conversations or other opportunities that occur, but should certainly be addressed in churches in the weeks following the disaster.

\section{Responses to Anxiety in the Absence of Buffers}

In the absence of the buffers described above, humans tend to respond to thoughts about their own death with various forms of anxiety, fear, sadness, and 
other forms of psychological malaise. To alleviate this discomfort and the oftenaccompanying sense of worthlessness, humans make various attempts to feel better, especially about themselves as illustrated in Figure 1. (Pyszczynski, Solomon, and Greenberg 2015; Rosenblatt et al. 1989; Greenberg, Pyszczynski, and Solomon 1986). What are some of the ways people can respond to this anxiety to avoid falling into despair during times of crisis when faced with the reality of their own mortality?

Adoption of a Worldview that Provides Safety. From a Christian point of view, one of the most important things that we can do is to help people find meaning and purpose in life, a meaning and purpose that transcends death and is found in Jesus Christ. When people are faced with their own finiteness and risk of eternal insignificance, experimental evidence indicates that they are motivated to seek a worldview that will deliver them from this despair (Juhl and Routledge 2016; Pyszczynski, Solomon, and Greenberg 2015). They are more likely to be open to the gospel when death is salient than when things are going well. "It is not those who are healthy who need a doctor, but the sick" (Luke 5:31, NIV).

In a recent experiment (Jackson et al. 2018), participants were given a test that supposedly indicated that they either believed or did not believe in God. Among those who were told that the test indicated that they believed in God, those who had claimed to believe in God responded with a low level of death anxiety and those who had claimed to be non-believers responded with a medium level of death anxiety. However, among those who were in the group who were told that the test indicated that they did not believe in God, believers responded with a medium level of death anxiety and non-believers responded with a high level. Both believers and nonbelievers increased in death anxiety when presented evidence that they did not believe in God compared to when they were presented evidence that they believed in God. This indicates that a lack of belief in God provokes anxiety, and thus provides experimental evidence, albeit indirect, that belief in God reduces death anxiety.

Similarly, Jong, Bluemke, and Halberstadt (2013) studied the relationship between belief in God and death-anxiety by using direct self-reports. For participants who self-identified as religious, the stronger they believed in God the less they feared death. However, for participants who self-identified as non-religious, the more they indicated that they believed in God, the more they feared death. In times of crisis, it is likely that these non-religious God-believers would be more open to adopting a worldview that would respond to their need for salvation than at times when death is not salient.

This same group of researchers (Jong, Halberstadt, and Bluemke 2012) also found evidence that belief in God becomes stronger for both the self-identified Christians and non-religious when they are primed to think of death. Similarly, when 
death is salient, belief in the possibility of divine intervention increases (Norenzayan and Hansen 2006) and willingness to listen to reasons for believing in God (Heflick and Goldenberg 2012) increases regardless of one's level of existing belief. These studies indicate, again, that during times of crisis, non-Christians are more likely to be open to the gospel and should be provided with opportunities to hear it, discuss it, and respond to it.

Another aspect of worldview that evolves when people think about their death concerns morality. In general, people's moral standards rise in the face of death and they have less tolerance for moral deviance in others (e.g., tolerance for prostitution; Rosenblatt et al. 1989; Greenberg and Arndt 2011). This could be due to simply a desire to conform to social norms, demonstrating one's value as a morally upright citizen. However, it may indicate an increased sensitivity to sin. Those who have great confidence in their worldview and believe that their moral uprightness will earn them either literal or figurative immortality may become less open to the gospel, but those who are unsatisfied with their worldview or have doubts might become more open. This means that people who are close to the gospel, the fence-sitters, may demonstrate a greater change in openness to the gospel during times of crisis than those who are hardened against it.

A recent meta-analysis (a composite of many quantitative studies on a single subject) indicates that there is a clear distinction between how nominal (or extrinsic) Christianity and evangelical (or intrinsic) Christianity influence one's response to thoughts about death (Gorsuch and McPherson 1989; Jong et al. 2018). The more one is extrinsically religious (performing religious behavior for the sake of personal and social benefits), the greater the death anxiety. In contrast, the more one is intrinsically religious (performing religious behavior because of the personal conviction of the truth of one's religious beliefs), the less the death anxiety. Once again this indicates that the religious, but not regenerated, might shift in their openness to the Gospel when faced with death more than those who strongly oppose Christian beliefs. To respond to the felt-needs of the not-yet-believers who may more readily attend a church service or meeting where the gospel is discussed after a largescale disaster, we should focus on communicating the gospel, emphasizing the meaning to life it provides and the promise of eternal life. Just as Paul in Romans emphasizes that no one, even using the standards of their own worldview, is good enough to merit justification before God, we need to communicate that such justification comes only through Jesus Christ (Rom. 1-5).

Validation of Existing Worldview. When people are not convinced of their worldview's answers concerning meaning and death, their worldview may be insufficient to buffer them from death anxiety. One response is to seek validation of one's worldview to become more sure of the immortality and meaning it offers. 
Support for one's worldview typically comes from listening to or interacting with others who are very convinced of its truth. Experiments show that people experience an increased desire for structure, coherence, and charismatic leaders who provide clear explanations for events when they are forced to reflect about death (Landau et al. 2004; Landau et al. 2009). This means that people who hold to a nominally Christcentered worldview may seek to better understand this worldview during times of natural disasters, terrorism, or other tragedies. Christian leaders should focus more than normal on providing reasons for the veracity of the Christian worldview, explaining why we can have faith in Christ and his Word and how people can experience eternal life, a more righteous and worthy life, and lives that positively impact others through love.

During global crises, data shows that people who identify as Christians will seek to affiliate with others who claim to share their worldview more than at other times (Greenberg et al. 1990). People tend to gravitate toward people who share their worldview and find them more attractive when death is salient. This means that in times of disaster, people who are associated with a Christian community will have greater motivation to draw together in fellowship and relationships will form easier. Such a time would be especially appropriate for forming new small groups within a church, providing younger leaders an opportunity to use their enthusiasm and passion during a time of need. Existing leaders should be ready at such times to provide these emerging leaders the structure and encouragement to form these groups.

The dual need for evangelism and fellowship should not be treated as distinct. As the church is the body of Christ (Eph. 4:1-16), fellowship with committed Christians should help the non-Christian understand who Jesus is and make a more informed decision about following him. Focusing on apologetics, reasons for believing in Christ and trusting his word (I Pet. 3:15), would be an especially fruitful topic during times when people are seeking affirmation of their worldview and making efforts to draw closer to others.

It should be noted that this phenomena of seeking affirmation of one's worldview may similarly lead to a rejection of other worldviews and dislike of those who hold them. Greenberg and colleagues (1990) found that nominal Christians (i.e., people who could identify the denominational affiliation of their family) disliked Jews more when death became salient. This was especially true with people high in authoritarianism. In general, nationalism and faith in one's own ingroup increases when people have to think about death (Burke, Martens, and Faucher 2010; Pyszczynski, Solomon, and Greenberg 2015). One study (Rothschild, Abdollahi, and Pyszczynski 2009) found that when death was salient, Americans high in Christian fundamentalism (e.g., people who agreed with the statement "God has given mankind a complete, unfailing guide to happiness and salvation, which must 
be totally followed," from Altemeyer and Hunsberger 1992) were much more supportive of the use of violence to solve problems in the Middle East (e.g., bomb Iran) than were people low in Christian fundamentalism. However, when the participants high in Christian fundamentalism read four Bible passages that emphasized compassion and love (Eph. 4:32, Matt. 7:1-2, Matt. 7:12, and Mark 12:31), their support of the use of violence dropped to the level of participants low in Christian fundamentalism. Thus, it appears the undesirable effects of outgroup derogation can be minimized by emphasizing the biblical values of love and compassion which were central in Jesus' proclamation of the gospel.

Relationship Seeking. When death is salient, people experiencing death anxiety may seek to enter into and develop relationships. As described above, relationships buffer against anxiety by providing protection from danger, access to physical and social resources, emotional comfort, a sense of community and value, and confirmation of one's worldview. People who have secure attachment styles (i.e., who typically have good close relationships), are even more attracted to others and desire to be close to them (Plusnin, Pepping, and Kashima 2018). People who are generally avoidant, especially males, also are more open to develop closer relationships than usual, with more interest in the non-sexual aspects of relationships than is the case when death is not salient (Landau et al. 2006). People generally become more concerned about others' worldview, seeking to be closer to people who share the same core values when they are forced to think about their own death (Kosloff et al. 2010; Plusnin, Pepping, and Kashima 2018).

Times of terror and disaster thus motivate people to meet others and develop new relationships. This is especially true for those who do not have effective buffers against death anxiety. Christian leaders should encourage people in their churches to reach out to non-Christian family and neighbors during these times; churches should provide activities where people can interact with one another and develop relationships. After the immediate physical dangers and threats have been addressed, Christian leaders need to provide programs and structures that will allow people to understand the disaster from a Christian perspective and develop relationships with those who hold such views.

Just as the awareness of death motivates people to form new relationships, experiments have demonstrated that mortality salience also motivates people to develop and deepen existing relationships. Because close relationships with people who share a similar worldview in such situations are seen as more important, people, especially those who tend to avoid close relationships, are more willing to invest time and effort in them (Cox and Arndt 2012; Plusnin, Pepping, and Kashima 2018). Similarly, people become more creative in problem solving and conflict management. Because of the importance of social connections after thinking about 
death, people are willing to exert the effort necessary to cooperate and resolve issues that might have been previously separating them (Greenberg, Solomon, and Arndt 2008).

Once again, this would indicate that times following disasters are especially appropriate for trying to incorporate marginal church members or attenders into the community. Because many are likely to seek deeper relationships with people who hold a solid worldview that provides a buffer against death anxiety, they are likely to make the effort necessary to more fully integrate into a community if they are provided the welcome and structure necessary to do so. During such times, rather than emphasizing the performance and entertainment aspects of a church's ministry to attract people, the accent should be placed on making sense out of the world from a Christian point of view, how a person's life can have purpose in spite of the disaster, and the family nature of Christian community characterized by close relationships.

Self-Enhancement. Another response to death anxiety is self-enhancement (Dufner et al. 2019; Solomon, Greenberg, and Pyszczynski 1991), creating and maintaining an positive image of oneself that raises one's self-esteem so as to reduce the anxiety associated with the possibility of living a short, meaningless life that may end poorly by meeting an omnipotent, righteous judge. From a Christian point of view, self-enhancement, which is closely associated with pride, arrogance, and selfdeception, is clearly an undesirable response to death anxiety. "God is opposed to the proud, but gives grace to the humble" (I Pet. 5:5b, NASB).

For Christians, this means we need to be especially concerned about pride and arrogance when our worldview is threatened, which might be the case during times of disaster. If our view of God and how he made the world does not include his use of such situations for his glory, we may begin to question our faith in him and his Word. Similarly, Christian leaders may find greater comfort in their abilities and status than in a God who is unpredictable. Narcissistic behavior is a real temptation for Christian leaders, especially in larger churches which may attract people who welcome the opportunity to be associated with someone who comes across as a superstar (Dunaetz, Jung, and Lambert 2018). A lack of humility in pastors is associated not only with opposition from God (I Pet. 5:5, Jam. 4:6), but with lower commitment in church members (Dunaetz, Cullum, and Barron 2018). Christian leaders need to make sure that coming face-to-face with the reality of their own mortality leads them to find their value in Christ, not in themselves.

In terms of evangelism and outreach, after the immediate physical needs of people have been met when a disaster hits, the priority should be given to the people who are unsure of their worldview or who only have weak social relations for support. Such times would not be the most effective to reach those who are firmly 
grounded in non-Christian worldviews, such as a local imam or an atheist who is known for arguing with Christians. It is likely that strongly supporting their own worldview in front of their own community will provide them with an effective buffer against death anxiety.

\section{Non-Christian Applications of Terror Management Theory}

Although the focus of this review has been on Christian applications of terror management theory to best demonstrate love and respond to the needs of those around us when disasters occur or during other times when people are especially aware of the certainty of death, this theory is often presented in a way that assumes that God does not exist and all religious belief is simply a human attempt to reduce death anxiety (Pyszczynski, Solomon, and Greenberg 2015; Burke, Martens, and Faucher 2010). Such presuppositions lead to conclusions that Christians can learn from in order to more effectively live consistently with the gospel, participate in the missio dei, and avoid mistakes in judgment that come from blind spots.

One of terror management's most supported predictions is that mortality salience often increases attachment to one's worldview and derogation or dismissal of other worldviews (Greenberg and Arndt 2011). This can lead to prejudice and discrimination against groups to which one does not belong. For example, one study (Arndt et al. 2009) found that nominally Christian medical students doing a diagnosis exercise grew more concerned about Christians and less concerned about Muslims when death was salient compared to when it was not. Greenberg et al. (1990), as mentioned earlier, found that Christians (i.e., people who could identify the denominational affiliation of their parents) became biased against Jews when made to think about death. Although these studies did not focus on evangelicals, they illustrate how easily some people become biased when death is salient. Such responses are not congruent with the gospel, especially Jesus' command to love even our enemies (Matt. 5:43-48). During a period when many people associate evangelicalism with xenophobia and right-wing politics (Labberton 2018; Fea 2018), insights from terror management theory should make Christian leaders question how accurately they are communicating the importance of love, humility, and serving others to the typical attender of evangelical churches.

Some terror management theory researchers believe that reducing the religious commitment of people will reduce the number of negative consequences associated with mortality salience. Burke and colleagues (2010) argue that strengthening one's worldview when thinking about death is generally negative because of the biases it creates. They recommend promoting more "prosocial" responses such as promoting attitudes of liberalism and tolerance, and developing a belief in symbolic immortality, a secure attachment style, and "an expanding circle 
of morality" (p. 116). These strategies most likely are quite effective at reducing Christians' commitment to a biblical worldview and are supported by many within liberal Christianity. However, evangelicals need to evaluate the cost involved in adopting such strategies.

\section{Conclusion}

Terror management theory describes how people respond in situations where they are forced to think about death. To find meaning and escape the existential terror that thoughts of their own death may evoke, people strengthen their faith in worldviews that provide them with significance and justification for their behavior. These worldviews buffer them from death anxiety. Other buffers may include close relationships or any other process that provides self-esteem. When global crises occur, such as terrorism, war, or natural disasters, death will certainly be salient. Christians should respond in a manner consistent with the gospel. After responding to people's immediate physical needs, they need to seek to respond to people's heightened sense of spiritual need as many will have an increased openness to the gospel which promises eternal life with God, meaning in the present life, and a place in God's overall purpose for the world to all who place their trust in Christ. Missionaries and other Christian leaders should use this openness to show people how to respond to the gospel and escape from the dread that they may be experiencing when death is salient.

\section{References}

Adler, Alfred. 1927. Understanding Human Nature. Translated by Walter Beran Wolfe. London, UK: George Allen \& Unwin Ltd.

Alicke, M. D., M. L. Klotz, D. L. Breitenbecher, T. J. Yurak, and D. S. Vredenburg. 1995. "Personal contact, individuation, and the better-than-average effect." Journal of Personality and Social Psychology 68 (5): 804825.

Allport, G. W. 1937. Personality: A psychological interpretation. New York, NY: Hold, Reinhart, \& Winston.

Altemeyer, B., and B. Hunsberger. 1992. "Authoritarianism, religious fundamentalism, quest, and prejudice." The International Journal for the Psychology of Religion 2 (2): 113-133.

Arndt, J., S. Solomon, T. Kasser, and K. M. Sheldon. 2004. "The urge to splurge: A terror management account of materialism and consumer behavior." Journal of Consumer Psychology 14 (3): 198-212.

Arndt, J., M. Vess, C. R. Cox, J. L. Goldenberg, and S. Lagle. 2009. "The psychosocial effect of thoughts of personal mortality on cardiac risk assessment." Medical Decision Making 29 (2): 175-181.

Becker, E. 1973. The Denial of Death. New York, NY: Free Press.

Burke, B. L., A. Martens, and E. H. Faucher. 2010. "Two decades of terror management theory: A meta-analysis of mortality salience research." Personality and Social Psychology Review 14 (2): 155-195.

Campbell, W. K., E. A. Rudich, and C. Sedikides. 2002. "Narcissism, self-esteem, and the positivity of self-views: Two portraits of self-love." Personality and Social Psychology Bulletin 28 (3): 358-368.

Cox, C. R., and J. Arndt. 2012. "How sweet it is to be loved by you: the role of perceived regard in the terror management of close relationships." Journal of Personality and Social Psychology 102 (3): 616-632.

Dufner, M., J. E. Gebauer, C. Sedikides, and J. J. A. Denissen. 2019. "Self-enhancement and psychological adjustment: A meta-analytic review." Personality and Social Psychology Review 23 (1): 48-72. 
Dunaetz, D. R. 2019. "Evangelism, Soical Media, and the Mum effect." Evangelical Review of Theology 43 (2): 138151.

Dunaetz, D. R., M. Cullum, and E. Barron. 2018. "Church Size, Pastoral Humility, and Member Characteristics as Predictors of Church Commitment." Theology of Leadership Journal 1 (2): 125-138.

Dunaetz, D. R., H. L. Jung, and S. S. Lambert. 2018. "Do Larger Churches Tolerate Pastoral Narcissism More than Smaller Churches?" Great Commission Research Journal 10 (1): 69-89.

Fea, J. 2018. Believe Me: The Evangelical Road to Donald Trump. Grand Rapids, MI: Wm. B. Eerdmans Publishing.

Gantt, P., and R. Gantt. 2012. "Disaster psychology: Dispelling the myths of panic." Professional Safety 57 (08): $42-$ 49.

George, A. R. 1999. The Epic of Gilgamesh: The Babylonian Epic Poem and Other Texts in Akkadian and Sumerian. London, UK: Penguin Books.

Gorsuch, R. L., and S. E. McPherson. 1989. "Intrinsic/extrinsic measurement: I/E-revised and single-item scales." Journal for the Scientific Study of Religion: 348-354.

Greenberg, J. 2005. Managing behavior in organizations. 4th ed. Upper Saddle River, NJ: Prentice Hall.

Greenberg, J., and J. Arndt. 2011. "Terror management theory." In The Handbook of Theories of Social Psychology, 398-415. Los Angeles, CA: Sage.

Greenberg, J., T. Pyszczynski, and S. Solomon. 1986. "The causes and consequences of a need for self-esteem: A terror management theory." In Public Self and Private Self, edited by R. F. Baumeister, 189-212. New York, NY: Springer.

Greenberg, J., T. Pyszczynski, S. Solomon, A. Rosenblatt, M. Veeder, S. Kirkland, and D. Lyon. 1990. "Evidence for terror management theory II: The effects of mortality salience on reactions to those who threaten or bolster the cultural worldview." Journal of Personality and Social Psychology 58 (2): 308-318.

Greenberg, J., S. Solomon, and J. Arndt. 2008. "A basic but uniquely human motivation." In Handbook of Motivation Science, 114-134.

Griffin, D., and K. Bartholomew. 1994. "Models of the Self and Other: Fundamental Dimensions Underlying Measures of Adult Attachment." Journal of Personality and Social Psychology 67: 430-445.

Grijalva, E., and P. D. Harms. 2014. "Narcissism: An integrative synthesis and dominance complementarity model." The Academy of Management Perspectives 28 (2): 108-127.

Heflick, N. A., and J. L. Goldenberg. 2012. "No atheists in foxholes: Arguments for (but not against) afterlife belief buffers mortality salience effects for atheists." British Journal of Social Psychology 51 (2): 385-392.

Horney, K. 1937. The Neurotic Personality of Our Time. New York, NY: Norton.

Jackson, J. C., J. Jong, M. Bluemke, P. Poulter, L. Morgenroth, and J. Halberstadt. 2018. "Testing the causal relationship between religious belief and death anxiety." Religion, Brain \& Behavior 8 (1): 57-68.

Jonas, E., J. Schimel, J. Greenberg, and T. Pyszczynski. 2002. "The Scrooge effect: Evidence that mortality salience increases prosocial attitudes and behavior." Personality and Social Psychology Bulletin 28 (10): 1342-1353.

Jong, J., M. Bluemke, and J. Halberstadt. 2013. "Fear of death and supernatural beliefs: Developing a new Supernatural Belief Scale to test the relationship." European Journal of Personality 27 (5): 495-506.

Jong, J., J. Halberstadt, and M. Bluemke. 2012. "Foxhole atheism, revisited: The effects of mortality salience on explicit and implicit religious belief." Journal of Experimental Social Psychology 48 (5): 983-989.

Jong, J., R. Ross, T. Philip, S.-H. Chang, N. Simons, and J. Halberstadt. 2018. "The religious correlates of death anxiety: A systematic review and meta-analysis." Religion, Brain \& Behavior 8 (1): 4-20.

Juhl, J., and C. Routledge. 2016. "Putting the terror in terror management theory: Evidence that the awareness of death does cause anxiety and undermine psychological well-being." Current Directions in Psychological Science 25 (2): 99-103.

Kastenbaum, R., and N. A. Heflick. 2010. "Sad to say: Is it time for sorrow management theory?" Omega: Journal for the Study of Death and Dying 62 (4): 305-327.

Kosloff, S., J. Greenberg, D. Sullivan, and D. Weise. 2010. "Of trophies and pillars: Exploring the terror management functions of short-term and long-term relationship partners." Personality and Social Psychology Bulletin 36 (8): 1037-1051.

Krueger, J. 1998. "Enhancement bias in descriptions of self and others." Personality and Social Psychology Bulletin 24 (5): 505-516.

Labberton, M. 2018. Still Evangelical? Downers Grove, IL: InterVarsity Press.

Landau, M. J., J. L. Goldenberg, J. Greenberg, O. Gillath, S. Solomon, C. Cox, A. Martens, and T. Pyszczynski. 2006. "The siren's call: Terror management and the threat of men's sexual attraction to women." Journal of Personality and Social Psychology 90 (1): 129-146. 
Landau, M. J., J. Greenberg, D. Sullivan, C. Routledge, and J. Arndt. 2009. "The protective identity: Evidence that mortality salience heightens the clarity and coherence of the self-concept." Journal of Experimental Social Psychology 45 (4): 796-807.

Landau, M. J., S. Solomon, J. Greenberg, F. Cohen, T. Pyszczynski, J. Arndt, C. H. Miller, D. M. Ogilvie, and A. Cook. 2004. "Deliver us from evil: The effects of mortality salience and reminders of 9/11 on support for President George W. Bush." Personality and Social Psychology Bulletin 30 (9): 1136-1150.

Leary, M. R., E. S. Tambor, S. K. Terdal, and D. L. Downs. 1995. "Self-esteem as an interpersonal monitor: the sociometer hypothesis." Journal of personality and social psychology 68 (3): 518-530.

Lebedun, M., and K. E. Wilson. 1989. "Planning and integrating disaster response." In Psychosocial Aspects of Disaster, 268-279. New York, NY: John Wiley \& Sons.

McNamara, P., R. Sosis, and W. J. Wildman. 2011. "Announcing a new journal: Religion, Brain \& Behavior." Religion, Brain \& Behavior 1 (1): 1-4.

Miller, D. T., and M. Ross. 1975. "Self-serving biases in the attribution of causality: Fact or fiction." Psychological Bulletin 82 (2): 213-225.

Moore, D. A., and P. J. Healy. 2008. "The trouble with overconfidence." Psychological Review 115 (2): $502-517$.

Norenzayan, A., and I. G. Hansen. 2006. "Belief in supernatural agents in the face of death." Personality and Social Psychology Bulletin 32 (2): 174-187.

Plusnin, N., C. A. Pepping, and E. S. Kashima. 2018. "The role of close relationships in terror management: A systematic review and research agenda." Personality and Social Psychology Review 22 (4): 307-346.

Pyszczynski, T., S. Solomon, and J. Greenberg. 2015. "Thirty years of terror management theory: From Genesis to Revelation." Advances in experimental social psychology 52: 1-70.

Rosenblatt, A., J. Greenberg, S. Solomon, T. Pyszczynski, and D. Lyon. 1989. "Evidence for terror management theory: I. The effects of mortality salience on reactions to those who violate or uphold cultural values." Journal of Personality and Social Psychology 57 (4): 681-690.

Rothschild, Z. K., A. Abdollahi, and T. Pyszczynski. 2009. "Does peace have a prayer? The effect of mortality salience, compassionate values, and religious fundamentalism on hostility toward out-groups." Journal of Experimental Social Psychology 45 (4): 816-827.

Solomon, Sheldon, Jeff Greenberg, and Tom Pyszczynski. 1991. "A terror management theory of social behavior: The psychological functions of self-esteem and cultural worldviews." Advances in Experimental Social Psychology 24: 93-159.

Vail, K. E., and M. Soenke. 2018. "The impact of mortality awareness on meaning in life among Christians and atheists." Religion, Brain \& Behavior 8 (1): 44-56.

Weinstein, N. D., and W. M. Klein. 1996. "Unrealistic optimism: Present and future." Journal of Social and Clinical Psychology 15 (1): 1-8.

Zaleskiewicz, T., A. Gasiorowska, and P. Kesebir. 2015. "The Scrooge effect revisited: Mortality salience increases the satisfaction derived from prosocial behavior." Journal of Experimental Social Psychology 59: 67-76. 